\title{
Re-envisioning community-wildfire relations in the U.S. West as adaptive governance
}

\author{
$\underline{\text { Jesse B. Abrams }}^{1}, \underline{\text { Melanie Knapp }}^{2,3}, \underline{\text { Travis B. Paveglio }}^{4}, \underline{\text { Autumn Ellison }}^{1}$, Cassandra Moseley ${ }^{1}, \underline{\text { Max Nielsen-Pincus }}^{5}$ and $^{\text {Matthew }}$
} S. Carroll $^{6}$

\begin{abstract}
Prompted by a series of increasingly destructive, expensive, and highly visible wildfire crises in human communities across the globe, a robust body of scholarship has emerged to theorize, conceptualize, and measure community-level resilience to wildfires. To date, however, insufficient consideration has been given to wildfire resilience as a process of adaptive governance mediated by institutions at multiple scales. Here we explore the possibilities for addressing this gap through an analysis of wildfire resilience among wildland-urban interface communities in the western region of the United States. We re-engage important but overlooked components of social-ecological system resilience by situating rural communities within their state- to national-level institutional contexts; we then analyze two communities in Nevada and New Mexico in terms of their institutional settings and responses to recent wildfire events. We frame our analysis around the concepts of scale matching, linking within and across scales, and institutional flexibility.
\end{abstract}

Key Words: disaster resilience; institutions; learning; scale-matching; wildfire; wildland-urban interface

\section{INTRODUCTION}

A decades-long pattern of increasingly large and destructive wildfires in places like the western United States, Australia, and the Mediterranean region has motivated a dialogue regarding the need to foster "fire adapted" or "fire resilient" human communities (Paton and Tedim 2012, Paveglio et al. 2012, Kulig et al. 2013, Prior and Eriksen 2013). This dialogue includes a range of academics, policy makers, and practitioners with interests in reducing the human, ecological, and financial toll of large wildfire events by encouraging more adaptive behaviors at the community level. Achieving the goal of greater community fire resilience, thereby allowing fire to play the regenerative role that it has played for millennia, is complicated by the multiscalar nature of the problem. The chief drivers of the wildfire dilemma in the U.S. West include episodic as well as longer term, anthropogenically driven climatic variability (Heyerdahl et al. 2002, Westerling et al. 2006); long-term wildland fuel accumulation because of a legacy of active fire suppression, past management practices, and other land uses (Covington and Moore 1994, Hessburg and Agee 2003, Miller et al. 2009); and the expansion of the wildland-urban interface (WUI), where human communities, structures, and infrastructure abut or intermix with flammable vegetation (Syphard et al. 2007, Theobald and Romme 2007, Hammer et al. 2009). These drivers intersect with a panoply of social, psychological, managerial, economic, and institutional challenges to create a seemingly intractable wicked problem (Carroll et al. 2007) for which there is no single or overarching solution.

The literature on human community relations with wildfire includes diverse scholarly perspectives and approaches. Key strands of scholarship include research on the perceptions, values, and motivations of individual WUI residents (e.g., McCaffrey 2006, Absher et al. 2009), community-scale processes and intercommunity variability (Carroll et al. 2005, Paveglio et al.
2009, 2012, 2015, Newman et al. 2013), and analyses of policies, budgets, organizational culture, incentives, and other institutional dimensions (Davis 2001, Steelman and Kunkel 2004, Steelman et al. 2004, Wise and Yoder 2007, Nowell and Steelman 2013, Spies et al. 2014). An overall conceptual shift from fire preparedness to fire resilience and the promotion of fire-adapted communities has introduced concepts from social-ecological system (SES) resilience theory to the body of wildfire scholarship. This trajectory parallels a trend within the larger disaster preparedness community, which has seen the disaster resilience concept become incorporated into national- and even international-level policies (Klein et al. 2003).

Resilience has been defined and operationalized in numerous and varied ways throughout the wildfire and community disaster preparedness literatures. Operational definitions of resilience often incorporate related concepts of adaptive capacity and vulnerability (Handmer and Dovers 1996, Paton 2006, Cutter et al. 2008, Norris et al. 2008, Paveglio et al. 2012). Community resilience is typically conceptualized as a set of assets, capacities, or community-level perceptions quantified in terms of dimensions such as social capital, social networks, competencies, neighborhood and economic resources, and community risk factors. In the specific context of wildfire, researchers have identified multiple individual and community-level factors associated with community resilience (Paveglio et al. 2009, Pooley et al. 2010, Kulig et al. 2013, Nowell and Steelman 2013). Despite the fact that the wildfire literature has clearly been influenced by resilience thinking, some important insights from the larger body of resilience scholarship have yet to be fully incorporated. First, although some fire scholars emphasize resilience as an adaptive process (e.g., Goldstein 2008, Nowell and Steelman 2013, van Niekerk 2014), the notion of resilience as an iterative cycle of management, learning, and adaptation at the local level remains largely absent as an analytical lens for understanding the

${ }^{1}$ Ecosystem Workforce Program, Institute for a Sustainable Environment, University of Oregon, ${ }^{2}$ U.S. Institute for Environmental Conflict Resolution, Morris K. Udall and Stewart L. Udall Foundation, ${ }^{3}$ previous: Ecosystem Workforce Program, Institute for a Sustainable Environment, University of Oregon, ${ }^{4}$ Department Of Natural Resources and Society, University of Idaho, ${ }^{5}$ Department of Environmental Science and Management, Portland State University, ${ }^{6}$ School of the Environment, Washington State University 
dynamics of human community coexistence with wildfire. Second, despite widespread acknowledgement of the importance of institutions and organizations in influencing wildfire management, analyses of institutional drivers and integration across scales remain underdeveloped in scholarship on community fire resilience. Indeed, much of the existing community fire adaptation literature focuses on individual residents in an implied institutional vacuum (Steelman 2008).

Our interest in the present work is to query what it might mean to reconnect theory with practice. How might we conceive of community wildfire resilience as a process driven and shaped by institutional dynamics? How might the notion of resilience as a process of adaptive governance be constructively applied to empirical studies of WUI communities? To offer initial answers to these questions, and to better understand the complex setting for community wildfire resilience, we re-engage here some of the key insights of resilience scholarship and apply them to the case of community coexistence with wildfire. We then examine the dynamics of two WUI communities that have experienced large wildfires in recent years to explore how attending to questions of institutions and adaptive governance could contribute to building community resilience.

\section{RE-ENGAGING RESILIENCE}

\section{Institutions and adaptive governance in fire resilience}

The concept of institutions is central to disciplines such as sociology, economics, and political science, and plays a central role in SES resilience research and practice. At least two broad conceptualizations are prominent across these fields: a social constructionist view sees institutions as taken-for-granted ways of being and behaving that structure people's core social realities; the neoinstitutional economic view, conversely, defines institutions largely as rules that constrain or modify the rational, utility-seeking activities of otherwise-autonomous beings (Vatn 2005). What both have in common is an understanding that institutions are relatively durable (Mahoney and Thelen 2009), that they can be either formal (e.g., laws) or informal (e.g., unwritten social expectations), and that they set the parameters for a wide range of social interactions, including those pertaining to environmental and natural resource management. As the formal or informal rules of the game, institutions guide the possibilities for adaptive or maladaptive social-ecological relationships by structuring interactions among various social groups, as well as between social groups and the environments with which they interact (Ostrom 1990, Gunderson et al. 1995, Holling et al. 2002, Elmqvist et al. 2003, Folke et al. 2003, Moore and Westley 2011, Leslie and McCabe 2013). Attention to organizations is central to the study of institutions because organizations tend to be strongly structured by institutions (Kiser and Ostrom 2000) and because they play key roles in processes of institutionalization (Scott 2014). Indeed, institutional change often occurs by and through organizations, whether those organizations are formal or informal and whether they represent state, market, or civil society actors or some combination of all three (North 1990).

Questions related to institutional settings and interactions inform a larger corpus of theorization and research regarding the resilience of SESs. Institutions can be seen to operate at three distinct levels to influence social action: operational, i.e., rules guiding individual action; collective choice, i.e., binding rules applied collectively to groups of people; and constitutional, i.e., procedural rules that structure collective-choice decisions (Ostrom 2005). Scholarship on adaptive governance, which captures many of the most important lessons of resilience thinking as applied to social organization, is centrally concerned with institutional arrangements at all three levels that allow for learning and adaptation to environmental variation (Dietz et al. 2003, Folke et al. 2005, Scholz and Stiftel 2005, Olsson et al. 2006, Djalante et al. 2011, Almstedt and Reed 2013, Cumming et al. 2013, Chaffin et al. 2014). The concept of adaptive governance is built upon the understanding that opportunities for improved social-ecological resilience emerge from processes of learning through collaboration, management, feedback, and adjustment, and that these dynamics reflect institutional influences at multiple scales. Adaptive governance emphasizes "the ability to observe and interpret essential processes and variables in ecosystem dynamics to develop the social capacity to respond to environmental feedback and change" (Folke et al. 2005:445). It has been identified as a constructive approach to managing wicked problems, where levels of social and ecological complexity overwhelm the ability of traditional bureaucratic or expert-driven management to arrive at acceptable outcomes (Brunner and Steelman 2005, Scholz and Stiftel 2005, Gunderson and Light 2006).

Insights from the adaptive governance literature regarding institutions and scale are particularly applicable to wildfire management in the U.S. West because the latter is characterized by institutional "thickness" and because community fire resilience is an inherently complex and multiscalar issue. We focus here on three broad lessons that to date remain underdeveloped in fire resilience scholarship. Resilience and adaptive governance scholarship suggest that the potential for learning and adaptation appears to be greatest (1) when scales are appropriately matched, meaning there is an alignment between decisions taken, direct experience with the outcome or consequences of those decisions, and responsibility for adaptive responses; (2) when there is communication and relationship building both across scales and across institutions and actors within scalar levels; and (3) when institutions and organizations are structured in such a way as to be receptive to new information and flexible enough to adapt in response. To date these insights have only infrequently been incorporated into community fire resilience scholarship, if at all; however, they are highly relevant to the project of creating more fire-resilient human communities as we describe below.

\section{Scale matching}

Questions of scale matching are prominent throughout the adaptive governance literature (Chaffin et al. 2014). Cumming et al. (2006) explain that scale mismatches result "when the scale of environmental variation and the scale of the social organization responsible for management are aligned in such a way that one or more functions of the social-ecological system are disrupted, inefficiencies occur, and/or important components of the system are lost." Resilience scholars emphasize the problems that arise when management decisions are made at one scale or by one entity while the consequences of those decisions are felt at other scales or borne by other entities; when higher level policies fail to recognize or support local-level constraints and opportunities; or 
when the incentives and time frames of social systems fail to align with the temporal dynamics of ecological systems (Lee 1993, Ludwig and Stafford Smith 2005, Borgström et al. 2006, Cumming et al. 2006). Frequently, potentially sustainable locallevel institutions are overruled or disenfranchised by higher level state or private institutions (Murphree 1993, Scott 1998, Petty et al. 2015). In response to the problem of resource domination by high-level bureaucracies, many resilience scholars have endorsed the subsidiarity principle, which states that governance authority should be "vested in the lowest level of social organization capable of solving pertinent problems" (Young 2002:284). Just what constitutes the level capable of problem solving, however, is not a simple question in the case of a multiscalar and wicked problem such as wildfire.

To date relatively little explicit attention has been paid to scale matching within the disaster and fire resilience literatures (see Baker and Refsgaard 2007, Birkmann and von Teichman 2010, and Ager et al. 2015 for exceptions). However, these concerns are clearly germane to questions of wildfire management. For example, fire researchers have noted the temporal misalignment between wildfire suppression activities and their long-run consequences (Calkin et al. 2015). Although suppression may be beneficial over the short term to protect human and ecological values at risk, institutionalization of the practice with ever-greater technologies of detection and control has contributed to increased fuel loads over the longer term, in essence priming the system for larger scale, more destructive fires given the right conditions (Carle 2002, Donovan and Brown 2007). Several recent policies in the United States have authorized extensive spending on vegetation treatments capable of reducing forest fuel loads and fuel continuity; however, implementation of the medium- to longterm project of fuel reduction and the reintroduction of beneficial fire is often complicated by social, managerial, and budgetary constraints (Stephens and Ruth 2005, Calkin et al. 2015). The short-term goal of wildfire suppression, meanwhile, continues to receive much greater appropriations, and there have been many instances in which federal fuel reduction budgets have been raided to pay for suppression cost overruns (Stephens and Ruth 2005, Steelman and Burke 2007, U.S. Forest Service 2015). Indeed, some communities that have invested years of effort to increase the scale of WUI fuel treatments have found their efforts limited by federal agency budget constraints and lack of bureaucratic support (Abrams 2011). Such cases underscore the mismatch between community-level efforts and the higher level institutions that drive key forest management decisions (see also González-Hidalgo et al. 2014).

Institutions related to wildfire planning and recovery also show evidence of scale mismatches. Gude et al. (2008) point to the problematic disconnect between the scale at which WUI residential development is governed (normally at the county scale in the western United States) and the largely national-level responsibility for fighting fire in these hazardous areas. Under this arrangement, many of the fire-related risks of continued WUI development are effectively socialized at the national scale while benefits are privatized at the household scale. Combined with the prioritization of fuel reduction in populated areas, federal wildfire management may even act as a public subsidy for continued WUI expansion (Cortner and Gale 1990, Busby and Albers 2010). Decisions regarding the rebuilding of lost homes and neighborhoods in the wake of a fire event are strongly influenced by higher scale influences such as homeowners' insurance, localto regional-planning frameworks, and the presence or absence of federal disaster relief funds (Davis 2001, Goldstein 2008, Kousky et al. 2012). As a result, the household- to community-scale entities responsible for residential development decisions may not be adequately incentivized or empowered to learn from and adapt to wildfire events.

\section{Linking within and across scales}

A concern with institutional and organizational linkages within and across scales complements attention to scale matching. Vertical and horizontal linkages facilitate the forging of ties and sharing of information among the various actors engaged in processes of environmental governance (Berkes 2002). Because local-level patterns and dynamics are inevitably affected, and in some cases, strongly driven or constrained, by higher level influences (Alcorn and Toledo 1998, Brondizio et al. 2009, Davidson 2013, Wilson 2013), successful adaptive governance is considered to be reliant upon a supportive framework of nested institutions (Folke et al. 2005). Two key challenges in this context are determining the appropriate roles and authorities at varying levels of a polycentric or multilevel governance structure and structuring communication and power sharing across these scalar levels (Pahl-Wostl 2009, Djalante et al. 2011, Pahl-Wostl et al. 2012, Bixler 2014). Resilience research points to the importance of bridging organizations that build social capital and create linkages for information sharing and adaptive learning in complex multiscalar settings (Cash et al. 2006, Crona and Parker 2012). Bridging organizations form vertical linkages between local communities and higher levels of organization, and may also link organizations horizontally within the same level (Olsson et al. 2007, Berkes 2009).

Cross-scale linkages are vital concerns in fire resilience in the United States, given that national-level agencies and programs play predominant roles in fire preparation, response, and recovery, influencing even state and local wildfire planning and capacity (Steelman et al. 2004). The U.S. Forest Service (USFS) and the Bureau of Land Management are particularly important agencies because of their management roles across both the vast public estates they manage and nearby nonfederal lands (Pyne 1982, Steelman et al. 2004). Although recent policy changes in the United States have attempted to devolve a degree of wildfire planning to communities at risk, federal-level institutions continue to control the allocation of resources for fire preparation and response on public lands, leaving many rural communities without adequate leverage to influence fire planning in their local areas (Steelman 2008, Fleeger and Becker 2010). Because the size of wildfires can vary from very small $(<1$ hectare) to landscape scale ( $>1$ million hectares), there is a need for fire response entities to scale up and down quickly, and multiagency coordination is common on larger fires (Lueck 2012). Further, effective disaster preparedness, response, and recovery often entail the successful integration of formal bureaucratic and informal emergent institutions (Nowell and Steelman 2013, Bosomworth et al. 2014). For example, Petty et al. (2015) note the divergent framing of fire risk between government agencies and WUI homeowners in Colorado as a key institutional misalignment. Communities in the United States have recently received authorization, guidance, and support in crafting collaborative wildfire planning 
documents, but these plans and the processes that create them remain relatively isolated from processes of feedback that could spur adaptive learning (Cheng et al. 2011).

Past research has also established the importance of social capital, i.e., relations of trust and reciprocity, in improving wildfire planning and management (Bihari and Ryan 2012, Lachapelle and McCool 2012). For example, the Fire Learning Network, led by The Nature Conservancy, an environmental nongovernmental organization (NGO), and composed of fire managers from diverse agencies and landscapes, utilizes collaboration across organizations and jurisdictions to result in new guiding narratives for institutional reform (Goldstein and Butler 2010) and the diffusion of fire management innovations across otherwiseisolated communities of practice (Butler and Goldstein 2010). Informal local social networks may also serve as key, if underappreciated, forums for sharing information and building social understanding of fire issues (Brenkert-Smith 2010). In the United States, bridging organizations of various kinds have been responsible for building organizational capacity for within- and cross-scale fire management learning and planning. Examples include state-organized Fire Safe Councils in California (Everett 2002, Ganz et al. 2007), grassroots organizations such as the San Diego Fire Recovery Network (Goldstein 2008), and multistakeholder community forestry organizations such as those profiled in Ruidoso, New Mexico (Steelman and Kunkel 2004), Arizona's White Mountains region (Fleeger 2008, Abrams 2011), and northeast Oregon (Fleeger and Becker 2010).

\section{Institutional flexibility}

A key consideration in adaptive governance is how particular institutions influence the ways that people are organized (e.g., as households, firms, communities, agencies, NGOs, societies) to respond to environmental signals, whether manifested as ongoing environmental variability or as episodic crises related to individual disturbance events such as wildfires. For example, institutional arrangements may incentivize actors to ignore or downplay important information in favor of maintaining the short-term status quo of control (Young 2002). Alternatively, more flexible, adaptable institutions (largely at the collectivechoice and constitutional levels) can allow individuals and organizations to take advantage of crises as learning opportunities to reorganize social-ecological relationships (Goldstein 2008). The construction of inclusive, scaleappropriate, adaptable institutions that incorporate local knowledge is considered to be an essential strategy for fostering resilient social-ecological relationships through cycles of experimentation-as-management and observation of environmental variability (Folke et al. 1998, Adger et al. 2005, Janssen et al. 2007, Moore and Westley 2011, Cumming et al. 2013). Unusual or episodic events such as wildfires thereby become beneficial crises capable of triggering periods of learning and adaptation (Folke et al. 2005).

In contrast to this ideal of flexible, adaptable institutions, the prevailing wildfire management situation in the United States has been interpreted as a "rigidity trap" because of "the organizational incentives, budget priorities, and professional practices of agency land managers" (Butler and Goldstein 2010). Rigidity traps stem from high levels of control and short-term resilience combined with a lack of adaptive learning (Holling et al. 2002). The long-term institutionalization of fire suppression, organized and led largely by federal entities, has its roots in forces that appear resistant to incorporating and adaptively responding to new information. For example, Pyne (1982) describes how the mid-twentieth-century USFS relied so heavily upon fire suppression for legitimacy and political support that it grew increasingly unable to acknowledge signals indicating problems with its full-suppression paradigm. The agency's commitment to a "war on fire" included not only an aggressive military-style assault on fire starts but also an ideological battle against scientists supportive of light or controlled burning, as well as an extensive public information campaign (Carle 2002). The federal focus on suppression across ownerships was also driven by sustained political pressure by private timber firms that benefited from publicly subsidized fire protection, providing strong external barriers to learning and adaptation (Hudson 2011). Indeed, to the extent that adaptive learning historically occurred in federal fire management, it was primarily learning how to increase the effectiveness of fire suppression rather than learning how to constructively coexist with an endemic ecological process (Busenberg 2004).

Federal agencies, including the USFS, began to shift away from the full-suppression paradigm in the 1970s in light of growing recognition of the ecological benefits of fire in fire-adapted ecosystems and in response to the increasing scale and ferocity of wildfires (Arno and Allison-Bunnell 2002). However, fire suppression continues to be the dominant practice across western U.S. landscapes, and the implementation of alternative strategies remains rare (Steelman and McCaffrey 2011, Gebert and Black 2012). A constellation of institutional influences reinforces this approach, including formal bureaucratic requirements (Steelman and McCaffrey 2011), budgetary drivers (Steelman 2008, Thompson et al. 2013), cultural attitudes and expectations (Goldstein and Butler 2010, Steelman and McCaffrey 2011), external political pressure (Canton-Thompson et al. 2008, Donovan et al. 2011), and incentives supporting short-term risk aversion (Donovan and Brown 2007, Canton-Thompson et al. 2008, Calkin et al. 2011, 2015). One result of this pattern of action is the perpetuation of what Goldstein (2008) calls the "guardianship model," in which WUI communities have come to expect that government fire crews will extinguish any fire that threatens them. This arrangement may lead to a lack of community engagement on fire issues and discourage communities from confronting the consequences of their own residential development decisions.

In summary, an adaptive governance approach to community fire resilience suggests that the resilience of any given community is, at least in part, a function of the multiscalar institutions that inform community development, natural resource management, and fire planning, response, and recovery. This approach also highlights questions of scale matching, linkages within and across scales, and institutional flexibility as key to understanding whether and how communities nested within higher scales of governance adapt in the face of environmental change. Although such insights have been reflected in historical and institutional analyses of fire management, they are often conspicuously absent from scholarship on community fire resilience. In the following case studies, we re-engage these key resilience concepts by applying them to two communities that have recently experienced 
large wildfire events. We pay particular attention to the organizations and institutions that structure residents' interactions with each other and with outside entities and, consequently, shape community responses to wildfire.

\section{METHODS}

In 2013-2014 the research team conducted case studies (Yin 2003) of fire adaptation in four rural communities recently affected by wildfires, selected for study because they represent distinct rural community types with varying levels of social, human, and financial capital, senses of place, and relationships with outside entities (Paveglio et al. 2015). Further, all are geographies that are relatively underrepresented in the extant U.S. West fire resilience literature, the latter typically focused on sites of recent large, expensive, and highly visible wildfires (e.g., California, Colorado Front Range, Arizona). In this paper we focus on two communities, the Caughlin Ranch neighborhood in Reno, Nevada, and the town of Raton, New Mexico. Each of our case study communities was researched using a combination of semistructured, qualitative key informant interviews $(n=34$ for Caughlin Ranch and $n=24$ for Raton) and review of secondary data such as planning, analysis, and fire management documents. Interviewees included but were not limited to homeowners, fire and emergency response managers, elected officials, members of neighborhood or community organizations, and representatives of state and federal agencies with knowledge of or duties related to the community in question. Questions explored topics related to fire preparedness, response, and recovery, with a focus on what changes, if any, the community enacted following its experience with the large wildfire or wildfires in question. Interview duration ranged from 20 minutes to 3 hours and in some cases included field tours of affected areas. Interviews were audio recorded and transcribed verbatim.

Researchers analyzed data collected via a two-step process: the first entailed rounds of discussion with research team members during field data collection, allowing us to build and test hypotheses as we collected data; the second step was a more structured process of interview transcript coding to develop emergent themes (Charmaz 2006, Saldaña 2009) once interview data had been transcribed. These themes were used to build analytic narratives of each case and to facilitate cross-case comparison. Themes related to institutions and scale emerged through this analytic process, although they were not the initial focus of the project. The emergence of these themes prompted an engagement with the literature on institutions and adaptive governance, which then influenced further development of analytic coding strategies in an iterative "interplay between induction and deduction" (Strauss and Corbin 1998:137).

\section{CASE STUDIES: CAUGHLIN RANCH, NEVADA, AND RATON, NEW MEXICO}

\section{Caughlin Ranch, Nevada}

Caughlin Ranch is a relatively affluent suburban community on the western outskirts of Reno, Nevada, situated near the boundary with the Humboldt-Toiyabe National Forest. The community's green, park-like setting, with an abundance of planted trees and shrubs as well as native desert vegetation, contrasts with the more arid landscape typical of the Reno area. Residential properties here are typically thickly planted with junipers and other flammable vegetation, often in very close proximity to the houses themselves. The community has been affected by two large wildfires in recent years. The 2007 Hawken Fire was a roughly 1100 -hectare burn that forced the evacuation of many Caughlin Ranch neighborhoods and resulted in some minor property damage. The 2011 Caughlin Fire burned 800 hectares on a mix of federal and private lands and led to the evacuation of more than 4000 residents from Caughlin Ranch and nearby communities. Although this blaze did not damage any homes within Caughlin Ranch, it destroyed 29 houses and damaged 8 in an adjacent neighborhood. Both fires began on the slopes west of Caughlin Ranch and were pushed eastward by the area's characteristic downslope and cross-slope winds.

Typical Caughlin Ranch residents were professionals or retirees, most having relocated from outside the local area. Interviewed residents reported relatively limited interactions and relationships with neighboring residents and identified very few communitylevel organizations. The most influential community organization in Caughlin Ranch was the neighborhood homeowners' association (HOA), which maintained strict covenants, codes, and restrictions (CCRs) related to home design, yard appearance, and homeowner use of common areas. For years, these CCRs strongly incentivized the placement of flammable vegetation near structures and presented formidable obstacles to the removal of existing vegetation. They also required that flammable cedar fences be placed around homesites and common areas. These poorly fire-adapted policies existed in tension with more fireconscious policies, such as a rule that prohibited wood shake roofing materials in the name of fire risk reduction. Some residents who attempted to advance understanding of and action related to wildfire issues by working within the HOA reported that their efforts were largely blocked by a constitutional-level institutional structure in which substantial changes to collectivechoice rules required overwhelming community support. However, most interviewed residents appeared to have very limited understandings of local fire ecology and underestimated their own exposure to fire risk; there was a large discrepancy between community fire risk as perceived by local residents and as assessed by fire officials. To the extent that residents believed action was needed, most felt it was the HOA's responsibility to make any needed changes.

The Caughlin Ranch community lacked strong upward linkages to relevant higher scale governmental organizations prior to the Hawken and Caughlin fires. There had been little to no interaction between the community and USFS managers, despite the fact that the latter entity manages much of the terrain immediately to the west of the community, in and near the source of the majority of the fires that had threatened Caughlin Ranch in the past. The local USFS unit had been active in performing hazardous fuels treatments, including forest thinning and the application of prescribed fire, but these activities were done in the absence of any ongoing interaction with the Caughlin Ranch community. The University of Nevada-Reno Cooperative Extension (UNR) created accessible, place-specific homeowner preparedness materials on the theme of Living With Fire but lacked the capacity to engage large numbers of homeowners within individual communities. Local chapters of Nevada Fire Safe Councils, which were community-scale organizations that showed some promise for engaging homeowners and connecting them to higher scale 
entities, were discontinued following a statewide budget accounting scandal.

The HOA enacted some modest changes in the wake of the community's experiences with the Hawken and Caughlin fires: (1) homeowners were no longer allowed to use bark mulch for residential landscaping; (2) the HOA grounds crew increased their activities to reduce hazardous fuels in the common areas between private parcels; and (3) the HOA worked with UNR to host community fire safety meetings and to develop procedures for replacing flammable vegetation with less flammable species. Although homeowners were not required to replace hazardous trees and shrubs following this change, some procedural barriers were removed for those who voluntarily chose to do so. Fire issues were also occasionally highlighted in the Caughlin Rancher, a magazine published by the HOA and distributed to community members. Community fire safety meetings were initially well attended following the fires, but interest dropped off steeply with time. The HOA's common-area fuel reduction activities contributed to the community's level of fire protection but they also reinforced for many homeowners the narrative that fire preparedness was someone else's responsibility and, furthermore, that those obligations were being met. Although HOA leaders recognized the need for more substantial changes in community fire preparedness, they themselves felt limited by residents' complacent attitudes even after two close calls. Given the HOA's accountability to homeowners, this lack of concern may have limited the possibilities for local institutional change.

Problems of horizontal integration also existed in Caughlin Ranch, largely because of processes beyond the community's immediate control. The spatial extent of the community crosses the political boundary between the city of Reno and Washoe County jurisdictions; fire protection responsibilities are likewise divided between the City of Reno Fire Department and the county-level Truckee Meadows Fire Protection District. Recent disputes between these two fire protection organizations left them without mutual aid agreements that would allow one entity to respond to a fire in the other's jurisdiction. Following the dispute, the two entities continued to operate under distinct response protocols and use different radio communications frequencies. This lack of horizontal coordination between the two primary fire response entities was particularly problematic because fire preparedness in Caughlin Ranch was typified by the guardianship model described above; citizens largely felt that fire preparation and adaptation were reducible to the suppression capacity of fire professionals and the work of the HOA in reducing fuels along fence lines and in common areas.

\section{Scale matching}

Two of the key challenges in Caughlin Ranch were motivating homeowners to remove or alter flammable vegetation adjacent to their homes and increasing their understanding of local fire ecology. The fact that the strongest local organization operated at the scale of the community, and crafted and enforced formal collective-choice rules that directly governed the actions of individual homeowners, meant that there was at least the possibility for appropriate scale matching to spur community action. The HOA's past success in limiting wood shake roofing materials was a clear benefit from a fire safety perspective, and the HOA's role in both resident communication and regulation of properties gave it tremendous potential power in shaping relations between people and the local environment. As explained below, the specific constitutional structure of the HOA prevented this potential from being fully met. There were no informal community-scale institutions or organizations that encouraged proactive homeowner engagement in fire planning and preparation.

\section{Linking within and across scales}

Organizational and institutional integration was a particular challenge in Caughlin Ranch, where public agencies and other actors remained relatively isolated from one another. For example, social capital among residents appeared to be limited, and there was almost no interaction between the community and the USFS unit conducting fire and fuel treatments on the community's border. In fact, most community interviewees mistakenly referred to the neighboring agency as the Bureau of Land Management, showing a basic lack of awareness about who managed the land where fires in this area tend to start. The lack of coordination between city and county fire response entities was also problematic, leaving many residents concerned about the level of fire protection they would receive in the case of another emergency. Nevada Fire Safe Councils appeared to hold potential to act as much-needed bridging organizations, but were discontinued as noted above, leaving a structural gap in institutional communication and coordination. UNR's Living with Fire program had in some senses attempted to fill this gap, but was limited by lack of capacity to carry out sufficient outreach and organization. The HOA had a good working relationship with the university, promoting outreach and educational materials as well as community workshops; UNR expertise was also integrated into the HOA's revised list of "fire safe" landscaping plant species.

\section{Institutional flexibility}

The HOA's mission was largely to protect property values; combined with the institutional difficulty of reforming CCRs and the persistence of the guardianship model, this meant that shortterm aesthetic quality tended to be prioritized over longer term fire resilience. To the extent that the HOA adapted its rules in the face of repeated experiences with fire, it was largely to change management direction on common areas; homeowners were largely not expected, either through formal rules or informal expectations, to change vegetative conditions on their private parcels. Aside from a rule change that facilitated the voluntary replacement of highly flammable with less flammable vegetation, the institutional incentives supporting the planting and persistence of hazardous fuels on private parcels remained in place. Interviewees reported that, despite several close calls, neither the HOA nor the fire response agencies were willing to require proactive vegetation management on private homesites. Homeowners interpreted this silence as an indication that the threat posed by wildfire was sufficiently low. Indeed, experience with the Hawken and Caughlin fires apparently did little to stimulate individual or collective learning about local fire ecology or fire hazards. The institutions driving the relationship between homeowners, local ecological conditions, and fire risk largely failed to adapt even in the face of repeated experience with destructive fire events. 


\section{Raton, New Mexico}

Raton, New Mexico, is situated at the base of pine-, oak-, and juniper-studded Rocky Mountain foothills just south of the state line with Colorado. An abundance of shuttered businesses along Main Street speaks to the community's economic decline following the withdrawal or diminution of the traditional strongholds of coal mining and horse racing. In contrast to much of the U.S. West, public land is relatively scarce in the landscape surrounding Raton. The exception is Raton's municipal watershed to the northeast of town, much of which is owned by the city and managed as Sugarite Canyon State Park on the New Mexico side of the state boundary and as state wildlife areas on the Colorado side. Local residents cherish the watershed not only as a source of municipal water but also for its recreational opportunities including fishing, hunting, camping, hiking, and horseback riding. In 2011 the Track Fire, which began north of Raton near the state line, burned at moderate to high severity through much of the municipal watershed on both sides of the border. Local fire entities were initially in charge of responding to the fire, but high winds, low humidity, and fuel continuity contributed to rapid spread and expansion, and a federal fire response team was soon called in. Many local fire officials remained active under the federal command structure, but the federal team was able to contribute resources that did not exist at the local level, including a DC-10 tanker that was widely credited with saving several homes at risk. By the time the fire was extinguished, it had burned 11,247 hectares and destroyed 19 structures. Emergency watershed engineering was implemented in the immediate wake of the fire. This watershed stabilization work, supported by a federal emergency watershed protection grant, was designed to protect the provisioning of potable water with protection of recreational values as a secondary priority.

In the years leading up to the Track Fire, emergency managers, municipal officials, and natural resource stakeholders had already become cognizant of the risk of large, potentially destructive fires because of multiple high-profile wildfire events across the West, including several in New Mexico and Colorado. The Sugarite Stewardship Group, a collaborative organization containing local, state, and federal agency officials as well as representatives of NGOs, higher education, landowners, and local businesses, began working together in 2004 to address the threat posed by uncharacteristic wildfire to the forested landscape of Sugarite Canyon State Park. The stewardship group took on analysis, planning, and implementation of mechanical interventions meant to restore the densely stocked forest to more fire-resilient conditions by reducing fuel continuity, thereby decreasing the risk of crown fire. Despite persistent disagreements over proper management actions that slowed implementation progress, the group succeeded in accomplishing 240 hectares of forest treatments within the watershed in the years prior to the Track Fire. The group's work was supported by funding sources at local, state, and federal levels, in part through the coordinating role played by a state-level Watershed and Forest Health team whose charge included supporting emerging collaborative and capacitybuilding efforts within local communities.

Three characteristics of this stewardship group are worthy of note. First, it acted as a platform for collaborative and adaptive learning, in the sense that the coalition experimented with different treatment strategies and was able to observe and learn from the outcomes: both short-term post-treatment outcomes and outcomes in the aftermath of the Track Fire, which burned at high severity throughout the watershed, including in treated areas. Second, the group included representatives from relevant agencies and entities from the local to the state and even national scales. Third, the group helped to build the social capital among these varied entities that is considered vital to the functioning of effective institutions for adaptive governance. Interviewees noted that this social capital was critical in allowing the rapid initiation of a local contractor's postfire watershed engineering work that was widely credited with preserving many of the waterprovisioning and recreational values of the watershed.

The Track Fire exposed several other vertical and horizontal integration problems, and the community's response in the wake of the burn shows some indications of adaptation. Colfax County, an active player in both the stewardship group and in emergency response for the Track Fire, created a full-time emergency manager position to oversee and coordinate emergency preparedness and planning, in effect linking protection and response institutions both horizontally and vertically. The county fire marshal created a new volunteer fire district structured as a rapid-response unit, charged with deploying quickly to the location in greatest need of assistance during an emergency. This and other rural fire districts were eligible to receive resources from a state-level funding source for equipment and facilities needed to increase fire response capacity. Additionally, the Raton fire chief prioritized the creation of mutual and automatic aid agreements with other regional emergency response organizations and initiated joint trainings among these entities. Despite these successes, many problems remained even three years after the Track Fire. Many neighborhoods on the fringes of the city remained plagued by high fuel loadings, though efforts to increase homeowner engagement and action have been initiated. Further, the political boundary between the states of New Mexico and Colorado posed issues of state-level horizontal coordination that could not be addressed by local entities alone.

\section{Scale matching}

Individuals representing key local, state, federal, and civil society entities constructed an organization at the watershed scale to proactively manage and learn at the watershed scale. Working within a largely supportive policy framework, this organization experimented with management practices in anticipation of fire risk and remained active in the wake of the Track Fire. Because of both budgetary limitations and internal disagreements, the group moved relatively slowly in implementing forest restoration prior to the Track Fire, and the scale and ferocity of the fire overwhelmed the treatments already put in place. No organizations or institutions existed at the community level to structure residential fire preparedness prior to the Track Fire. This was reflected in the fact that many WUI homeowners had not undertaken substantial fire preparation prior to 2011.

\section{Linking within and across scales}

The stewardship group was instrumental in linking diverse entities working at multiple scales of governance and in building social capital among otherwise-isolated individuals. Local-level capacity was supported in part by higher scale programs, including federal funding for collaborative planning and implementation as well as state-level financial and organizational 
support. In the wake of the fire, state-level resources devoted to rural fire protection supported further local action. Although agreement on treatment prescriptions within the stewardship group was difficult to achieve, the deliberative process helped to build social capital among group members that allowed for a modest level of project implementation, suggesting at least partial resolution to a wicked problem. This social capital was leveraged in the immediate wake of the fire when a local contractor received broad social support to perform emergency watershed stabilization work, a project supported financially by the City of Raton and a federal emergency grant. Perhaps the greatest challenge to coordination was related to complications with interorganizational integration across the New Mexico-Colorado state line. This political boundary divides Raton's watershed, subjecting the two sides to different collective-choice and operational rules for fire planning and response. Although this concern was broadly recognized, it was difficult to address because state-level policies presented formidable barriers to greater coordination.

\section{Institutional flexibility}

According to many stewardship group members, the Track Fire served as a learning opportunity for those involved in deliberations regarding forest treatments, fire response, and postfire watershed stabilization. Tangible indicators of adaptation after the fire were most clear in the case of organizing for effective fire planning and response. The establishment of a county-level emergency manager position with an explicit coordinating role, the creation of a spatially flexible, on-demand fire protection district, and the increase in mutual aid agreements and joint trainings were all innovations stimulated by the community's experience with the Track Fire. Such changes suggest that institutional rigidity was low and that key organizations and actors were flexible and adaptable in the face of new information. Group members also report having learned from observing the extreme fire behavior and forest impacts of the Track Fire, and some changed their perceptions of the effectiveness of the management practices enacted prior to the burn.

\section{DISCUSSION AND CONCLUSIONS}

Our analytic framework interprets community wildfire resilience in these communities as an iterative process of learning and adaptation whose contours are influenced by the scale at which institutions and organizations operate, the ways in which they structure interactions between actors at various scales, and their ability to adapt in the face of new information. Caughlin Ranch and Raton were both embedded in long-term, large-scale climatic and vegetative changes over which they had little immediate control, yet they represented divergent approaches in terms of their community-scale institutions and organizations. Despite strengthening linkages between the HOA and the cooperative extension, as well as implementation of some modest changes to HOA regulations, Caughlin Ranch showed signs of institutional rigidity. This was reflected in the overall lack of substantive changes to fire-related planning, response preparation, and crossorganizational interactions, as well as in continued low levels of fire hazard awareness on the part of WUI residents. Raton, by contrast, had built organizational linkages around fire and forest management prior to the Track Fire and showed greater evidence of adaptive responses in the fire's aftermath. Changes to fire planning and preparation were much more substantial than in Caughlin Ranch, and the building and strengthening of relationships across jurisdictional and political boundaries were a major focus following the fire. The stewardship group in this case played a bridging role by creating a common forum for community, county, state, and federal representatives, as well as nearby landowners, researchers, and other interested parties, to share information and resources and build social capital. Aside from the defunct Nevada Fire Safe Councils, no true bridging organizations existed in Caughlin Ranch.

Our analysis of these two cases highlights some of the multiscalar institutional and organizational dimensions that appear to have affected adaptation in the wake of direct experiences with large fires. Our argument here is not that institutions and organizations matter more than other components of social relationships with fire, such as values, leadership, place attachment, exposure to expert information, or similar factors typically emphasized in community fire resilience research. Rather, we suggest that in the case of wildfire, as with other ecological processes, institutions and organizations play key roles in structuring social opportunities to learn from and adapt to ecosystem dynamics and that, to date, this analytic focus has been underdeveloped. Attending to questions of institutions and scale reframes fire resilience in subtle but important ways. Instead of being imagined as autonomous actors, communities are seen as both constrained and empowered by higher scale influences. Instead of being framed as isolated decision makers, homeowners and other residents are positioned as agents embedded in sets of rules, incentives, cultures, social networks, and tacit expectations that structure their relationships to local environments. The concept of fire resilience itself, often implicitly defined as adequate homeowner and emergency manager preparation for fire, becomes instead redefined in terms of adaptive governance of social and ecological systems at multiple scales.

At the same time, institutions and organizations should not be seen as independent of other social forces but rather as coconstitutive of them. For example, the differences between Raton and Caughlin Ranch were not solely institutional; rather, their local institutional contexts reflected underlying features of the people, organizations, histories, and ecological settings in each location. Characteristics of the Caughlin Ranch HOA reflected the values and expectations of the people living in that community, even as the HOA's rules and activities acted to structure residents' relations with one another and with the land. Likewise, Raton's Sugarite Stewardship Group both reflected and recursively shaped the missions, knowledge sets, and actions of those within the group. Given the diversity of WUI communities across the U.S. West (Paveglio et al. 2015), the institutional diversity surrounding wildfire planning, response, and recovery should come as no surprise. Further, it should be noted that Raton suffered greater direct impacts from the Track Fire than Caughlin Ranch did from the Hawken and Caughlin fires; this fact may also have played a role in the divergence of the two community responses.

WUI communities in the western United States face unique challenges in building the capacity to learn and perhaps even benefit from the large wildfires that have become a common presence on the landscape. Because of the predominance of 
federal-level institutions in wildfire preparation, response, and recovery, it may be difficult for actors at the local level to organize in ways that influence many of the key drivers of the wildfire rigidity trap. This is not to say, however, that communities stand helpless in the face of prevailing institutional arrangements. Although they may have little leverage to affect, for example, federal agency budgets and incentive structures, communities can organize local entities (including local representatives of state and federal organizations) in ways that create opportunities for adaptive governance, just as higher level entities can support and incentivize social organization and learning at local levels.

The Caughlin Ranch experience, for example, suggests that HOAs can play important roles in structuring community fire adaptation, but only if their institutional structures incentivize learning and adaptation among community residents. Absent such institutional arrangements, HOAs may serve instead to insulate community members from responsibility and may even encumber and interrupt processes of adaptive learning. The Raton example suggests that the participation of relevant entities from multiple agencies operating at multiple scales in common deliberation and learning forums can increase social capital and lead to opportunities for adaptation in the wake of fire events. Both cases also highlight the important roles played by state-level entities: in Nevada the elimination of the Fire Safe Council program left an institutional void within vulnerable communities; in New Mexico, state-level programs supported both community groups like the Sugarite Stewardship Group and local fire response entities.

The insight that flexible institutions, well aligned across scales, contribute to learning and constructive adaptation to environmental variability is not a new one. However, scholars, policy makers, and practitioners are still working to understand the range of possibilities for such institutions in the face of the unique and complex challenge of human habitation in fire-prone communities. The analysis presented here suggests that, in addition to taking into account factors emphasized in prior fire resilience research, we should pay close attention to institutions and organizations at multiple scalar levels. This dimension of community wildfire resilience resonates with many of the fundamental insights of resilience thought and practice.

Responses to this article can be read online at: http://www.ecologyandsociety.org/issues/responses. $\mathrm{php} / 7848$

\section{Acknowledgments:}

The authors would like to thank the residents and stakeholders of our case study communities for their time and insights. Thanks also to Nick Goulette at the Watershed Research and Training Center. This project was supported by the USDA National Institute of Food and Agriculture, Grant \#2011-67023-30695.

\section{LITERATURE CITED}

Abrams, J. 2011. The policy context of the White Mountain stewardship contract. Pages 163-176 in D. Egan, E. Hjerpe, and J. Abrams, editors. Human dimensions of ecological restoration: integrating science, nature, and culture. Island Press, Washington, D.C., USA. http://dx.doi.org/10.5822/978-1-61091-039-2_12

Absher, J. D., J. J. Vaske, and L. B. Shelby. 2009. Residents' responses to wildland fire programs: a review of cognitive and behavioral studies. U.S. Department of Agriculture, Forest Service, Pacific Southwest Research Station, Albany, California, USA.

Adger, W. N., T. P. Hughes, C. Folke, S. R. Carpenter, and J. Rockström. 2005. Social-ecological resilience to coastal disasters. Science 309(5737):1036-1039. http://dx.doi.org/10.1126/science.1112122

Ager, A. A., J. D. Kline, and A. P. Fischer. 2015. Coupling the biophysical and social dimensions of wildfire risk to improve wildfire mitigation planning. Risk Analysis. 35(8):1393-1406. http://dx.doi.org/10.1111/risa.12373

Alcorn, J. B., and V. M. Toledo. 1998. Resilient resource management in Mexico's forest ecosystems: the contribution of property rights. Pages 216-249 in F. Berkes and C. Folke, editors. Linking social and ecological systems: management practices and social mechanisms for building resilience. Cambridge University Press, Cambridge, UK.

Almstedt, Å., and M. G. Reed. 2013. Introducing a framework for good and adaptive governance: an application to fire management planning in Canada's boreal forest. Forestry Chronicle 89(5):664-674. http://dx.doi.org/10.5558/tfc2013-119

Arno, S. F., and S. Allison-Bunnell. 2002. Flames in our forest: disaster or renewal? Island Press, Washington, D.C., USA.

Baker, D., and K. Refsgaard. 2007. Institutional development and scale matching in disaster response management. Ecological Economics 63(2-3):331-343. http://dx.doi.org/10.1016/j. ecolecon.2007.01.007

Berkes, F. 2002. Cross-scale insitutional linkages: perspectives from the bottom up. Pages 293-321 in E. Ostrom, T. Dietz, N. Dolsak, P. C. Stern, S. Stonich, and E. U. Weber, editors. The drama of the commons. National Academy Press, Washington, D. C., USA.

Berkes, F. 2009. Evolution of co-management: role of knowledge generation, bridging organizations and social learning. Journal of Environmental Management 90(5):1692-1702. http://dx.doi. org/10.1016/j.jenvman.2008.12.001

Bihari, M., and R. Ryan. 2012. Influence of social capital on community preparedness for wildfires. Landscape and Urban Planning 106(3):253-261. http://dx.doi.org/10.1016/j. landurbplan.2012.03.011

Birkmann, J., and K. von Teichman. 2010. Integrating disaster risk reduction and climate change adaptation: key challengesscales, knowledge, and norms. Sustainability Science 5 (2):171-184. http://dx.doi.org/10.1007/s11625-010-0108-y

Bixler, R. P. 2014. From community forest management to polycentric governance: assessing evidence from the bottom up. Society \& Natural Resources 27(2):155-169. http://dx.doi. org/10.1080/08941920.2013.840021

Borgström, S. T., T. Elmqvist, P. Angelstam, and C. AlfsenNorodom. 2006. Scale mismatches in management of urban landscapes. Ecology and Society 11(2):16. [online] URL: http:// www.ecologyandsociety.org/vol11/iss2/art16 
Bosomworth, K., J. Handmer, and S. Dovers. 2014. Learning from analyses of policy frames and informal institutions in the fire management sector of Victoria, Australia. Pages 269-289 in B. C. Glavovic and G. P. Smith, editors. Adapting to climate change: lessons from natural hazards planning. Springer, Dordrecht, Netherlands. http://dx.doi.org/10.1007/978-94-017-8631-7_11

Brenkert-Smith, H. 2010. Building bridges to fight fire: the role of informal social interactions in six Colorado wildland-urban interface communities. International Journal of Wildland Fire 19 (6):689-697. http://dx.doi.org/10.1071/wf09063

Brondizio, E. S., E. Ostrom, and O. R. Young. 2009. Connectivity and the governance of multilevel social-ecological systems: the role of social capital. Annual Review of Environment and Resources 34:253-278. http://dx.doi.org/10.1146/annurev.environ.020708.100707

Brunner, R. D., and T. A. Steelman. 2005. Beyond scientific management. Pages 1-46 in R. D. Brunner, T. A. Steelman, L. Coe-Juell, C. M. Cromley, C. M. Edwards, and D. W. Tucker, editors. Adaptive governance: integrating science, policy, and decision making. Columbia University Press, New York, New York, USA.

Busby, G., and H. J. Albers. 2010. Wildfire risk management on a landscape with public and private ownership: who pays for protection? Environmental Management 45(2):296-310. http://dx. doi.org/10.1007/s00267-009-9381-x

Busenberg, G. 2004. Wildfire management in the United States: the evolution of a policy failure. Review of Policy Research 21 (2):145-156. http://dx.doi.org/10.1111/j.1541-1338.2004.00066.x

Butler, W. H., and B. E. Goldstein. 2010. The US Fire Learning Network: springing a rigidity trap through multiscalar collaborative networks. Ecology and Society 15(3):21. [online] URL: http://www.ecologyandsociety.org/vol15/iss3/art21/

Calkin, D. C., M. A. Finney, A. A. Ager, M. P. Thompson, and K. M. Gebert. 2011. Progress towards and barriers to implementation of a risk framework for US federal wildland fire policy and decision making. Forest Policy and Economics 13 (5):378-389. http://dx.doi.org/10.1016/j.forpol.2011.02.007

Calkin, D. E., M. P. Thompson, and M. A. Finney. 2015. Negative consequences of positive feedbacks in US wildfire management. Forest Ecosystems 2(1):9. http://dx.doi.org/10.1186/s40663-015-0033-8

Canton-Thompson, J., K. M. Gebert, B. Thompson, G. Jones, D. Calkin, and G. Donovan. 2008. External human factors in incident management team decisionmaking and their effect on large fire suppression expenditures. Journal of Forestry 106 (8):416-424.

Carle, D. 2002. Burning questions: America's fight with nature's fire. Praeger, Westport, Connecticut, USA.

Carroll, M. S., K. A. Blatner, P. J. Cohn, and T. Morgan. 2007. Managing fire danger in the forests of the US Inland Northwest: a classic "wicked problem" in public land policy. Journal of Forestry 105(5):239-244.

Carroll, M. S., P. J. Cohn, D. N. Seesholtz, and L. L. Higgins. 2005. Fire as a galvanizing and fragmenting influence on communities: the case of the Rodeo-Chediski fire. Society \& Natural Resources 18(4):301-320. http://dx.doi.org/10.1080/089$\underline{41920590915224}$
Cash, D. W., W. N. Adger, F. Berkes, P. Garden, L. Lebel, P. Olsson, L. Pritchard, and O. Young. 2006. Scale and cross-scale dynamics: governance and information in a multilevel world. Ecology and Society 11(2):8. [online] URL: http://www.ecologyandsociety. org/vol11/iss2/art8/

Chaffin, B. C., H. Gosnell, and B. A. Cosens. 2014. A decade of adaptive governance scholarship: synthesis and future directions. Ecology and Society 19(3):56. http://dx.doi.org/10.5751/ ES-06824-190356

Charmaz, K. 2006. Constructing grounded theory: a practical guide through qualitative analysis. Sage, Thousand Oaks, California, USA.

Cheng, A. S., T. Steelman, and C. Moseley. 2011. Examining changes in wildfire policy and governance in the United States through three analytical lenses. Pages 24-32 in S. M. McCaffrey and C. L. Fisher, editors. Proceedings of the Second Conference on the Human Dimensions of Wildland Fire. U.S. Department of Agriculture, Forest Service, Northern Research Station, Newtown Square, Pennsylvania, USA.

Cortner, H. J., and R. D. Gale. 1990. People, fire, and wildland environments. Population and Environment 11(4):245-257. http:// dx.doi.org/10.1007/bf01256458

Covington, W. W., and M. M. Moore. 1994. Postsettlement changes in natural fire regimes and forest structure: ecological restoration of old-growth ponderosa pine forests. Journal of Sustainable Forestry 2(1-2):153-181. http://dx.doi.org/10.1300/ j091v02n01 07

Crona, B. I., and J. N. Parker. 2012. Learning in support of governance: theories, methods, and a framework to assess how bridging organizations contribute to adaptive resource governance. Ecology and Society 17(1):32. http://dx.doi. org/10.5751/ES-04534-170132

Cumming, G. S., D. H. M. Cumming, and C. L. Redman. 2006. Scale mismatches in social-ecological systems: causes, consequences, and solutions. Ecology and Society 11(1):14. [online] URL: http://www.ecologyandsociety.org/vol11/iss1/ $\underline{\operatorname{art} 14 /}$

Cumming, G. S., P. Olsson, F. S. Chapin, III, and C. S. Holling. 2013. Resilience, experimentation, and scale mismatches in socialecological landscapes. Landscape Ecology 28(6):1139-1150. http://dx.doi.org/10.1007/s10980-012-9725-4

Cutter, S. L., L. Barnes, M. Berry, C. Burton, E. Evans, E. Tate, and J. Webb. 2008. A place-based model for understanding community resilience to natural disasters. Global Environmental Change 18(4):598-606. http://dx.doi.org/10.1016/j.gloenvcha.2008.07.013

Davidson, D. J. 2013. We still have a long way to go, and a short time to get there: a response to Fikret Berkes and Helen Ross. Society \& Natural Resources 26(1):21-24. http://dx.doi. org/10.1080/08941920.2012.749758

Davis, C. 2001. The West in flames: the intergovernmental politics of wildfire suppression and prevention. Publius 31(3):97-110. http://dx.doi.org/10.1093/oxfordjournals.pubjof.a004911

Dietz, T., E. Ostrom, and P. C. Stern. 2003. The struggle to govern the commons. Science 302(5652):1907-1912. http://dx.doi. org/10.1126/science.1091015 
Djalante, R., C. Holley, and F. Thomalla. 2011. Adaptive governance and managing resilience to natural hazards. International Journal of Disaster Risk Science 2(4):1-14. http://dx. doi.org/10.1007/s13753-011-0015-6

Donovan, G. H., and T. C. Brown. 2007. Be careful what you wish for: the legacy of Smokey Bear. Frontiers in Ecology and the Environment 5(2):73-79. http://dx.doi.org/10.1890/1540-9295 (2007)5[73:bcwywf]2.0.co;2

Donovan, G. H., J. P. Prestemon, and K. Gebert. 2011. The effect of newspaper coverage and political pressure on wildfire suppression costs. Society \& Natural Resources 24(8):785-798. http://dx.doi.org/10.1080/08941921003649482

Elmqvist, T., C. Folke, M. Nyström, G. Peterson, J. Bengtsson, B. Walker, and J. Norberg. 2003. Response diversity, ecosystem change, and resilience. Frontiers in Ecology and the Environment 1(9):488-494. http://dx.doi.org/10.1890/1540-9295(2003)001[0488: rdecar]2.0.co;2

Everett, Y. 2002. Community participation in fire management planning: a case from California, USA. Pages 125-133 in P. Moore, D. Ganz, L. C. Tan, T. Enters, and P. B. Durst, editors. Communities in flames: proceedings of an international conference on community involvement in fire management. Food and Agriculture Organization of the United Nations, Bangkok, Thailand.

Fleeger, W. E. 2008. Collaborating for success: community wildfire protection planning in the Arizona White Mountains. Journal of Forestry 106(2):78-82.

Fleeger, W. E., and M. L. Becker. 2010. Decision processes for multijurisdictional planning and management: community wildfire protection planning in Oregon. Society \& Natural Resources 23(4):351-365. http://dx.doi.org/10.1080/08941920802120067

Folke, C., F. Berkes, and J. Colding. 1998. Ecological practices and social mechanisms for building resilience and sustainability. Pages 415-436 in F. Berkes and C. Folke, editors. Linking social and ecological systems: management practices and social mechanisms for building resilience. Cambridge University Press, Cambridge, UK.

Folke, C., J. Colding, and F. Berkes. 2003. Synthesis: building resilience and adaptive capacity in social-ecological systems. Pages 352-387 in F. Berkes, J. Colding, and C. Folke, editors. Navigating social-ecological systems: building resilience for complexity and change. Cambridge University Press, Cambridge, UK. http://dx.doi.org/10.1017/cbo9780511541957.020

Folke, C., T. Hahn, P. Olsson, and J. Norberg. 2005. Adaptive governance of social-ecological systems. Annual Review of Environment and Resources 30:441-473. http://dx.doi.org/10.1146/ annurev.energy.30.050504.144511

Ganz, D., A. Troy, and D. Saah. 2007. Community involvement in wildfire hazard mitigation and management: community based fire management, fire safe councils and community wildfire protection plans. Pages 143-164 in A. Troy and R. G. Kennedy, editors. Living on the edge. Advances in the economics of environmental resources, Volume 6. Emerald Group, Bingley, UK. http://dx.doi.org/10.1016/s1569-3740(06)06009-3
Gebert, K. M., and A. E. Black. 2012. Effect of suppression strategies on federal wildland fire expenditures. Journal of Forestry 110(2):65-73. http://dx.doi.org/10.5849/jof.10-068

Goldstein, B. E. 2008. Skunkworks in the embers of the Cedar Fire: enhancing resilience in the aftermath of disaster. Human Ecology 36(1):15-28. http://dx.doi.org/10.1007/s10745-007-9133-6

Goldstein, B. E., and W. H. Butler. 2010. The US Fire Learning Network: providing a narrative framework for restoring ecosystems, professions, and institutions. Society \& Natural Resources 23(10):935-951. http://dx.doi.org/10.1080/08941920903012494

González-Hidalgo, M., I. Otero, and G. Kallis. 2014. Seeing beyond the smoke: the political ecology of fire in Horta de Sant Joan (Catalonia). Environment and Planning A 46:1014-1031. http://dx.doi.org/10.1068/a45600

Gude, P., R. Rasker, and J. Van den Noort. 2008. Potential for future development on fire-prone lands. Journal of Forestry 106 (4):198-205.

Gunderson, L., and S. S. Light. 2006. Adaptive management and adaptive governance in the everglades ecosystem. Policy Sciences 39(4):323-334. http://dx.doi.org/10.1007/s11077-006-9027-2

Gunderson, L. H., C. S. Holling, and S. S. Light, editors. 1995. Barriers and bridges to the renewal of ecosystems and institutions. Columbia University Press, New York, New York, USA.

Hammer, R. B., S. I. Stewart, and V. C. Radeloff. 2009. Demographic trends, the wildland-urban interface, and wildfire management. Society \& Natural Resources 22(8):777-782. http:// dx.doi.org/10.1080/08941920802714042

Handmer, J. W., and S. R. Dovers. 1996. A typology of resilience: rethinking institutions for sustainable development. Organization \& Environment 9(4):482-511. http://dx.doi.org/10.1177/1086026$\underline{69600900403}$

Hessburg, P. F., and J. K. Agee. 2003. An environmental narrative of inland northwest United States forests, 1800-2000. Forest Ecology and Management 178(1-2):23-59. http://dx.doi. org/10.1016/S0378-1127(03)00052-5

Heyerdahl, E. K., L. B. Brubaker, and J. K. Agee. 2002. Annual and decadal climate forcing of historical fire regimes in the interior Pacific Northwest, USA. Holocene 12(5):597-604. http:// dx.doi.org/10.1191/0959683602h1570rp

Holling, C. S., L. H. Gunderson, and G. D. Peterson. 2002. Sustainability and panarchies. Pages 63-102 in L. H. Gunderson and C. S. Holling, editors. Panarchy: understanding transformations in human and natural systems. Island Press, Washington, D.C., USA.

Hudson, M. 2011. Fire management in the American West: forest politics and the rise of megafires. University Press of Colorado, Boulder, Colorado, USA.

Janssen, M. A., J. M. Anderies, and E. Ostrom. 2007. Robustness of social-ecological systems to spatial and temporal variability. Society \& Natural Resources 20(4):307-322. http://dx.doi. org/10.1080/08941920601161320

Kiser, L. L., and E. Ostrom. 2000. The three worlds of action: a metatheoretical synthesis of institutional approaches. Pages 56-88 in M. D. McGinnis, editor. Polycentric games and institutions: 
readings from the workshop in political theory and policy analysis. University of Michigan Press, Ann Arbor, Michigan, USA.

Klein, R. J. T., R. J. Nicholls, and F. Thomalla. 2003. Resilience to natural hazards: how useful is this concept? Environmental Hazards 5(1):35-45.

Kousky, C., S. Olmstead, and R. Sedjo. 2012. In harm's way: homeowner behavior and wildland fire policy. Pages 178-199 in K. M. Bradshaw and D. Lueck, editors. Wildfire policy: law and economics perspectives. Resources for the Future, New York, New York, USA.

Kulig, J. C., D. S. Edge, I. Townshend, N. Lightfoot, and W. Reimer. 2013. Community resiliency: emerging theoretical insights. Journal of Community Psychology 41(6):758-775. http:// dx.doi.org/10.1002/jcop. 21569

Lachapelle, P. R., and S. F. McCool. 2012. The role of trust in community wildland fire protection planning. Society \& Natural Resources 25(4):321-335. http://dx.doi.org/10.1080/08941920.2011.569855

Lee, K. N. 1993. Greed, scale mismatch, and learning. Ecological Applications 3(4):560-564.

Leslie, P., and J. T. McCabe. 2013. Response diversity and resilience in social-ecological systems. Current Anthropology 54 (2):114-143. http://dx.doi.org/10.1086/669563

Ludwig, J. A., and M. D. Stafford Smith. 2005. Interpreting and correcting cross-scale mismatches in resilience analysis: a procedure and examples from Australia's rangelands. Ecology and Society 10(2):20. [online] URL: http://www.ecologyandsociety. org/vol10/iss $2 / \operatorname{art} 20 /$

Lueck, D. 2012. Economics and the organization of wildfire suppression. Pages 71-88 in K. M. Bradshaw and D. Lueck, editors. Wildfire policy: law and economics perspectives. Resources for the Future, New York, New York, USA.

Mahoney, J., and K. Thelen. 2009. A theory of gradual institutional change. Pages 1-37 in J. Mahoney and K. Thelen, editors. Explaining institutional change: ambiguity, agency, and power. Cambridge University Press, Cambridge, UK. http://dx. doi.org/10.1017/cbo9780511806414.003

McCaffrey, S., editor. 2006. The public and wildland fire management: social science findings for managers. U.S. Department of Agriculture, Forest Service, Northern Research Station, Newtown Square, Pennsylvania, USA.

Miller, J. D., H. D. Safford, M. Crimmins, and A. E. Thode. 2009. Quantitative evidence for increasing forest fire severity in the Sierra Nevada and Southern Cascade mountains, California and Nevada, USA. Ecosystems 12(1):16-32. http://dx.doi.org/10.1007/ $\underline{\text { s10021-008-9201-9 }}$

Moore, M.-L., and F. Westley. 2011. Surmountable chasms: networks and social innovation for resilient systems. Ecology and Society 16(1):5. [online] URL: http://www.ecologyandsociety. org/vol16/iss1/art5/

Murphree, M. 1993. Communities as resource management institutions. International Institute for Environment and Development, London, UK.

Newman, S. M., M. S. Carroll, P. J. Jakes, and T. B. Paveglio. 2013. Land development patterns and adaptive capacity for wildfire: three examples from Florida. Journal of Forestry 111(3):167-174. http://dx.doi.org/10.5849/jof.12-066

Norris, F. H., S. P. Stevens, B. Pfefferbaum, K. F. Wyche, and R. L. Pfefferbaum. 2008. Community resilience as a metaphor, theory, set of capacities, and strategy for disaster readiness. American Journal of Community Psychology 41(1-2):127-150. http://dx.doi.org/10.1007/s10464-007-9156-6

North, D. C. 1990. Institutions, institutional change and economic performance. Cambridge University Press, Cambridge, UK. http://dx.doi.org/10.1017/cbo9780511808678

Nowell, B., and T. Steelman. 2013. The role of responder networks in promoting community resilience: toward a measurement framework of network capacity. Pages 232-257 in N. Kapcu, C. V. Hawkins, and F. I. Rivera, editors. Disaster resiliency: interdisciplinary perspectives. Routledge, New York, New York, USA.

Olsson, P., C. Folke, V. Galaz, T. Hahn, and L. Schultz. 2007. Enhancing the fit through adaptive co-management: creating and maintaining bridging functions for matching scales in the Kristianstads Vattenrike Biosphere Reserve, Sweden. Ecology and Society 12(1):28. [online] URL: http://www.ecologyandsociety. org/vol12/iss1/art28

Olsson, P., L. H. Gunderson, S. R. Carpenter, P. Ryan, L. Lebel, C. Folke, and C. S. Holling. 2006. Shooting the rapids: navigating transitions to adaptive governance of social-ecological systems. Ecology and Society 11(1):18. [online] URL: http://www. ecologyandsociety.org/vol11/iss1/art18

Ostrom, E. 1990. Governing the commons: the evolution of institutions for collective action. Cambridge University Press, Cambridge, UK. http://dx.doi.org/10.1017/cbo9780511807763

Ostrom, E. 2005. Understanding institutional diversity. Princeton University Press, Princeton, New Jersey, USA.

Pahl-Wostl, C. 2009. A conceptual framework for analysing adaptive capacity and multi-level learning processes in resource governance regimes. Global Environmental Change 19(3):354-365. http://dx.doi.org/10.1016/j.gloenvcha.2009.06.001

Pahl-Wostl, C., L. Lebel, C. Knieper, and E. Nikitina. 2012. From applying panaceas to mastering complexity: toward adaptive water governance in river basins. Environmental Science \& Policy 23:24-34. http://dx.doi.org/10.1016/j.envsci.2012.07.014

Paton, D. 2006. Disaster resilience: building capacity to co-exist with natural hazards and their consequences. Pages 3-10 in D. Paton and D. Johnston, editors. Disaster resilience: an integrated approach. Charles C. Thomas, Springfield, Illinois, USA.

Paton, D., and F. Tedim, editors. 2012. Wildfire and community: facilitating preparedness and resilience. Charles C. Thomas, Springfield, Illinois, USA.

Paveglio, T. B., M. S. Carroll, P. J. Jakes, and T. Prato. 2012. Exploring the social characteristics of adaptive capacity for wildfire: insights from Flathead County, Montana. Human Ecology Review 19(2):110-124.

Paveglio, T. B., P. J. Jakes, M. S. Carroll, and D. R. Williams. 2009. Understanding social complexity within the wildland-urban 
interface: a new species of human habitation? Environmental Management 43(6):1085-1095. http://dx.doi.org/10.1007/s00267-009-9282$\underline{Z}$

Paveglio, T. B., C. Moseley, M. S. Carroll, D. R. Williams, E. J. Davis, and A. P. Fischer. 2015. Categorizing the social context of the wildland urban interface: adaptive capacity for wildfire and community "archetypes." Forest Science 61(2):298-310. http://dx. doi.org/10.5849/forsci.14-036

Petty, A. M., C. Isendahl, H. Brenkert-Smith, D. J. Goldstein, J. M. Rhemtulla, S. A. Rahman, and T. C. Kumasi. 2015. Applying historical ecology to natural resource management institutions: lessons from two case studies of landscape fire management. Global Environmental Change 31:1-10. http://dx.doi.org/10.1016/ j.gloenvcha.2014.11.004

Pooley, J. A., L. Cohen, and M. O'Connor. 2010. Bushfire communities and resilience: what can they tell us? Australian Journal of Emergency Management 25(2):33-38.

Prior, T., and C. Eriksen. 2013. Wildfire preparedness, community cohesion and social-ecological systems. Global Environmental Change 23(6):1575-1586. http://dx.doi.org/10.1016/j. gloenvcha.2013.09.016

Pyne, S. J. 1982. Fire in America: a cultural history of wildland and rural fire. Princeton University Press, Princeton, New Jersey, USA.

Saldaña, J. 2009. The coding manual for qualitative researchers. Sage, Los Angeles, California, USA.

Scholz, J. T., and B. Stiftel. 2005. The challenges of adaptive governance. Pages 1-11 in J. T. Scholz and B. Stiftel, editors. Adaptive governance and water conflict: new institutions for collaborative planning. Resources for the Future, Washington, D. C., USA.

Scott, J. C. 1998. Seeing like a state: how certain schemes to improve the human condition have failed. Yale University Press, New Haven, Connecticut, USA.

Scott, W. R. 2014. Institutions and organizations: ideas, interests, and identities. Fourth edition. Sage, Los Angeles, California, USA.

Spies, T. A., E. M. White, J. D. Kline, A. P. Fischer, A. Ager, J. Bailey, J. Bolte, J. Koch, E. Platt, C. S. Olsen, D. Jacobs, B. Shindler, M. M. Steen-Adams, and R. Hammer. 2014. Examining fire-prone forest landscapes as coupled human and natural systems. Ecology and Society 19(3):9. http://dx.doi.org/10.5751/ ES-06584-190309

Steelman, T. A. 2008. Communities in wildfire policy. Pages 109-126 in E. M. Donoghue and V. Sturtevant, editors. Forest community connections: implications for research, management and governance. Resources for the Future, Washington, D.C., USA.

Steelman, T. A., and C. Burke. 2007. Is wildfire policy in the United States sustainable? Journal of Forestry 33:67-72. http://dx. doi.org/10.2139/ssrn.1931057

Steelman, T. A., G. Kunkel, and D. Bell. 2004. Federal and state influence on community responses to wildfire threats: Arizona, Colorado, and New Mexico. Journal of Forestry 102(6):21-27.
Steelman, T. A., and G. F. Kunkel. 2004. Effective community responses to wildfire threats: lessons from New Mexico. Society \& Natural Resources 17(8):679-699. http://dx.doi. org/10.1080/08941920490480697

Steelman, T. A., and S. M. McCaffrey. 2011. What is limiting more flexible fire management-public or agency pressure? Journal of Forestry 109(8):454-461.

Stephens, S. L., and L. W. Ruth. 2005. Federal forest-fire policy in the United States. Ecological Applications 15(2):532-542. http:// dx.doi.org/10.1890/04-0545

Strauss, A. L., and J. M. Corbin. 1998. Basics of qualitative research: techniques and procedures for developing grounded theory. Sage, Thousand Oaks, California, USA.

Syphard, A. D., V. C. Radeloff, J. E. Keeley, T. J. Hawbaker, M. K. Clayton, S. I. Stewart, and R. B. Hammer. 2007. Human influence on California fire regimes. Ecological Applications 17 (5):1388-1402. http://dx.doi.org/10.1890/06-1128.1

Theobald, D. M., and W. H. Romme. 2007. Expansion of the US wildland-urban interface. Landscape and Urban Planning 83 (4):340-354. http://dx.doi.org/10.1016/j.landurbplan.2007.06.002

Thompson, M. P., D. E. Calkin, M. A. Finney, K. M. Gebert, and M. S. Hand. 2013. A risk-based approach to wildland fire budgetary planning. Forest Science 59(1):63-77. http://dx.doi. org/10.5849/forsci.09-124

U.S. Forest Service. 2015. The rising cost of fire operations: effects on the Forest Service's non-fire work. U.S. Department of Agriculture, Forest Service, Washington, D.C., USA.

van Niekerk, D. 2014. From burning to learning: adaptive governance to wildfires in the North-West Province of South Africa. Journal of Human Ecology 48(2):329-339.

Vatn, A. 2005. Institutions and the environment. Edward Elgar, Cheltenham, UK.

Westerling, A. L., H. G. Hidalgo, D. R. Cayan, and T. W. Swetnam. 2006. Warming and earlier spring increase western U. S. forest wildfire activity. Science 313(5789):940-943. http://dx. doi.org/10.1126/science.1128834

Wilson, G. A. 2013. Community resilience, policy corridors and the policy challenge. Land Use Policy 31:298-310. http://dx.doi. org/10.1016/j.landusepol.2012.07.011

Wise, C., and A. J. Yoder. 2007. Policy and institutional arrangements in federal wildland fire mitigation. Pages 187-206 in T. C. Daniel, M. S. Carrol, C. Moseley, and C. Raish, editors. People, fire, and forests: a synthesis of wildfire social science. Oregon State University Press, Corvallis, Oregon, USA.

Yin, R. K. 2003. Case study research: design and methods. Sage, Thousand Oaks, California, USA.

Young, O. R. 2002. Institutional interplay: the environmental consequences of cross-scale interactions. Pages 263-291 in E. Ostrom, T. Dietz, N. Dolsak, P. C. Stern, S. Stonich, and E. U. Weber, editors. The drama of the commons. National Academy Press, Washington, D.C., USA. 